\title{
University-Industry Business Incubators in Taiwan
}

\author{
Wen-Bo Wang ${ }^{1 *}$, Ying-Cheng Hung ${ }^{2}$, Chu-Ching Wang ${ }^{2}$ \\ ${ }^{1}$ Graduate Institute of Management Sciences, Tamkang University, New Taipei City, Taiwan \\ ${ }^{2}$ Department of Business Administration, Tamkang University, New Taipei City, Taiwan \\ Email: *wenbo1950@yahoo.com.tw, aloha@tku.edu.com.tw, chuching@mail.tku.edu.tw
}

Received March 10, 2013; revised April 20, 2013; accepted April 28, 2013

Copyright (C) 2013 Wen-Bo Wang et al. This is an open access article distributed under the Creative Commons Attribution License, which permits unrestricted use, distribution, and reproduction in any medium, provided the original work is properly cited.

\begin{abstract}
According to World Economic Forum data, if an area's average income per capita is over 9000 US dollars, then knowledge and technological innovation will be the most important forces driving its economic growth. In Taiwan 98\% of the companies are small and medium enterprises (SMEs), and they play a fundamental role in the sustainable development of Taiwan's economy, but due to limited funding, very few of them have established research and development (R\&D) departments. Over 70\% of the R \& D resources in Taiwan are held by universities, which have become hubs for new knowledge and technologies. Through university-industry collaboration, original and breakthrough ideas, inventions, and innovations are systematically channeled from universities into industrial applications and used to develop an entrepreneurial economy. This method has been proven effective in many developing countries. This paper examines how the government policy helps university incubators enhance R \& D ability and subsequently promote production efficiency and product quality.
\end{abstract}

Keywords: Research and Development; University-Industry Collaboration; Small and Medium Enterprises; Incubator

\section{Introduction}

According to the National Business Incubation Association [1] business incubators help entrepreneurs translate their ideas into workable and sustainable businesses by guiding them from the inception to being able to become a growing and thriving business. Business incubation provides entrepreneurs with expertise, networks and tools that they need to make their ventures successful.

With 163 colleges and universities, Taiwan has one of the highest densities of higher education institutions in the world in 2011. There are currently 98 college-level institutes with innovation incubators in Taiwan. There are also 11 corporately funded innovation incubators in the area. An abundance of academic and research manpower and R \& D achievements paired together with the entrepreneurial spirit of Taiwan's people creates suitable conditions for developing an entrepreneurial economy in Taiwan. Encouraging individual and corporate innovation not only helps to stimulate the area's economy, but is also crucial in guiding industries into top positions.

\section{Literature Review}

[2] Pointed out, incubation as an activity which links

\footnotetext{
"Corresponding author.
}

effectively, technology, capital and know-how to leverage entrepreneurial talent, accelerate the development of new companies, and thus speed the commercialization of technology.

Although [3] has raised concerns in combining research on university technology incubators with other incubators, this definition remains apposite for this paper with some qualifying statements. The majority of technology incubators are supported in full, or in part, by government programs offering a training ground for entrepreneurs and they are focused more on the commercialization of science and/or technology-oriented applications [4].

Policymakers therefore view technology incubators as instruments for achieving wider overarching goals related to global competitiveness through the facilitation of knowledge/technology transfer, an increase in innovatory potential and a greater propensity to turn ideas into commercial proposals [5].

In Taiwan the development of technology based incubators originates from the government that the promotion of such activity will foster the building of a "knowledgebased" economy that is robust enough to compete in the global market place. Government intervention is thought the necessity of the market that limits the ability of small 
technology-based firms to survive and of entrepreneurs to overcome the uncertainty and obstacles associated with the early stages of firm creation.

SMEs are an integral part of the economy and an important source of components and materials for the larger industries. The Government of Taiwan has realized that the key elements of a better environment for nurturing business are an enterprise culture, good infrastructure, strong business and education links and a highly efficient market, and has established comprehensive programs to help SMEs overcome the constraints of size and resources. One such program involves networking. This is being used extensively to tap the expertise and resources of the private and public sectors in order to reach out to the numerous SMEs. The network includes universities, technical colleges, training institutes and centers, Chambers of Commerce and business associations, banks and financial institutions, consultancies, large companies and Government agencies. This has resulted in assistance from both the private and public sectors and has improved the performance of SMEs and transformed them into more vibrant organizations with innovative ideas, better management and more responsive corporate structures.

In Taiwan , many technology, financial and marketing support institutions and programs exist for industries. The industrial structure in Taiwan has been traditionally dominated by SMEs and numerous institutions exist to facilitate their development.

For instance, the Industrial Technology Research Institute (ITRI) carries out projects related to applied R\&D of key technologies and components to help industries enhance their competitiveness in local and international markets.

Business incubation programs in various forms are also offered by subregional organizations. For instance, the APEC Cener for Technology Exchange and Training for SMEs is intended to support the sustainable development and growth of SMEs in the Asia and Pacific region and at the same time make them globally competitive.

\section{Research Methods}

In this study, we use content analysis, to compare the difference of National University Incubators in Taiwan and Massachusetts Institute of Technology (MIT) Incubators.

Content analysis is a systematic and objective method through the confirmation message of the characteristic article taken as the basis for inference. In the early stages of development, content analysis was used in mass media especially in the form of newspapers or magazines so the earlier content analysis method is mainly used in communication, journalism and other fields. [6] (Geiger \&
Martin 1999).

Today content analysis method has been widely used in other social sciences and behavioral sciences as a major data analysis method.

[7] Yang Xiaorong (1996) states that content analysis is a qualitative research technique, through a standardized unit of measurement and displays the characteristics of the text (communication content).

[8] Mei-Hui (2000) states that the main value of content analysis is not just an analysis of the data, but through content analysis we will manifest the influence of information and achieve the real purpose of the study.

[7] Yang Xiaorong (1996) unified all the above theories, and concluded that content analysis is defined as:

1) In approach: focus on objective, systematic and qualitative research methods.

2) In range: analyze not only the dissemination of the contents of the message, but also as the entire communication process.

3) In value: we need the analysis not just for the dissemination of the contents of the narrative explanation, but also as the inference of the dissemination of the contents of the entire communication process that occurs.

4) On the unit of analysis: the dissemination of content uses a variety of language features.

\section{Definition of Incubators}

Incubators concept has significantly evolved from the archetypal incubators of the 1950s. This concept leads to more attention paid to the interaction between the community and the incubator.

There are many definitions for incubators such as: effective talent link, technology transfer, capital movement, and technical know-how in order to leverage entrepreneurial talent and to accelerate the development of new companies [9].

However, [10] provides a narrower definition by stating that incubators nurture and grow start-ups in the Internet economy. They offer fledgling companies office space, funding, and basic services such as: recruiting, accounting, and legal advice, usually in exchange for equity stakes.

According to [11] the definition of incubator is a business support process that accelerates the successful development of start-up and fledgling companies by providing entrepreneurs with an array of targeted resources and services. These services are usually developed or orchestrated by incubator management and through network of contacts. An incubator's main goal is to produce successful firms that will leave the program financially viable and freestanding. These business incubator graduates have the potential to create jobs, revitalize neighborhoods, commercialize new technologies, and strengthen local and national economies. Critical to the defini- 
tion of a business incubator is the provision of management guidance, technical assistance and consulting tailored to young growing companies. Business incubators usually also provide clients access to appropriate rental space and flexible leases, shared basic business services and equipment, technology support services and assistance in obtaining the financing necessary for company growth.

[12] Define an incubator is a shared office space facility that seeks to provide start-ups and newer firms with a strategic, value-adding intervention system (i.e. business incubation) of monitoring and business assistance. This system controls and links resources with the objective of facilitating successful new venture development. When discussing the incubator, it is important to keep in mind the totality of the incubator, including a network of individuals and organizations [6].

\section{Evolution of Incubators}

The first business incubators were established in the USA in the 1950s [13,14] was created by Joseph Mancuso in Batavia, New York in 1957 on a former Massey-Ferguson facility $[15,16]$. The concept became widespread in the 1980s and spread to the rest of the world in a variety of forms (business centers, innovation centers, etc.) [17]. The incubator movement was initiated by the managers of the incubators in the United States through a series of conferences in the mid-1980s sponsored by the US Small Business Administration Agency [18,19]. Incubators differed from the existing industrial parks and estates, as the focus shifted away from real estate development and subsidized rents to value-added business services [16]. These developments finally led to the foundation of NBIA in 1985, with 40 founding members. For instance, University Research Park (URP) is a derivative of the concept of incubator. The main differences are the contractual and/or formal ownership or operational relationship with a university, as well as the focus on transfer of technology and promotion of R \& D under universityindustry partnership.

\section{Goals of Incubation Programs}

1) Create Job Opportunities: Incubators are seen as effective tools for creating self-employment opportunities, conventional product or service companies, and highgrowth companies. Incubators also are used to foster innovation, transfer technology, and impart an entrepreneurial spirit [20-23].

2) Enhance Economic Development: Incubators are used as much for spurring regional economic development and establishing industry clusters as they are for revitalizing urban environments and industry [24-28].

3) Build Global Networks: Incubators can also be used to build global networks of SMEs and incubators can be used to create business profits [20,23].

\section{Stages of Incubation}

There are three stages of incubation $[1,20,28]$ as follows:

1) Start-up creation stage (Preincubation): relates to the overall activities needed to support the potential entrepreneur in developing his/her business idea, business model, business plan, and to boost the chances to arrive to an effective startup creation.

2) Early stage (Incubation): concerns with the support given to the entrepreneur from the start-up to the expansion phase. Typically this is a mid-term process, lasting usually for the first three years of activity of the newly established company, which are the years in which it is safe to say whether the new venture is successful and has a good chance to develop into a fully mature company. The actions activated generally are: access to finance, direct coaching and mentoring services, as well as hosting services and specific training. Therefore, physical incubation, although a very important service, is a subset of the overall incubation process.

3) Expansion stage (Post-incubation): relates to the activities to be carried out when the company has reached the maturity phase, and therefore is ready to walk on its own feet. The company will leave the incubator, if it has been physically incubated. Innovation-based incubators work in the intersection between the sets of innovation and entrepreneurship supporting entrepreneurs to profit from the added value of innovative ideas.

\section{Incubation Policy in Taiwan}

The Small and Medium Enterprise Administration (SMEA) Ministry of Economic Affairs (MOEA) began encouraging the establishment of Small and Medium Enterprises (SMEs) innovation incubators by encouraging state-owned and private-sector enterprises in 1994. Over the next 6 years, nearly 60 incubators were set up as part of the plan to stimulate economic service provided by incubators. In support of the "Challenge 2008National Development Program” the 6-year Development Plan of “Asia-Pacific Entrepreneurship Center” was launched in 2002, to construct an innovation incubation platform for SMEs. The platform provided SMEs and start-ups in Taiwan with advice and assistance on the technologies, know-how and capital they needed. The learning mechanism for new start-ups was aimed at constructing a knowledge-based enterprising society.

The Executive Yuan decided in 2006 that the contribution to industrial innovation from industrial-academic cooperation should be increased. In the following year, the MOEA, Ministry of Education (MOE) and National Science Council (NSC) formed the Integrating Industry- 
Academia Collaboration Cross-Department Task Force. The working group was charged with offering universities incentives to integrate their academic R \& D, technology transfer, and business incubation organizations for maximum effectiveness.

The MOEA was assigned the task of using SMEs innovation incubators as the basis for value-added industry-academia R \& D. The "Value-adding Industry-Academia Cooperation through Incubation Program" was formally launched in 2008 to construct an industry incubation network, cultivate incubation expertise, and improve the incubation environment. Specialization, networking and improvement were made the key principles for helping incubators enhance their ability to provide value-adding services and a super-charged development environment for new start-ups.

The goal of the program is to cultivate up to 800 new start-up enterprises through the incubators within four years to realize the vision of "building an internationally competitive innovative SMEs cluster and guiding the industries towards breakthrough-oriented economic development," thereby helping Taiwan become a cradle for global creativity, innovation, and entrepreneurship (see Figure 1).

The global financial crisis of 2008 induced many governments around the world to implement short-term programs to reduce unemployment. During this time the spirit of entrepreneurship became particularly important due to the critical role it plays in long-term economic recovery, innovation, and sustainable development.

The SMEA adjusted its incubation policy and action strategies the following year to strengthen the integration of incubators, venture assistance organizations, and regional entrepreneurship and innovation service networks. "Improving the start-up incubation environment" and "establishing information and knowledge platform for entrepreneurship" and "financing start-up businesses" were defined as the three main strategies in the "Entrepreneurship Navigation Program" for creating a favorable environment for new ventures and encouraging entrepreneurship.

The SMEA set up regional service networks to better meet the needs of local businesses and help Taiwanese SMEs and micro-enterprises survive the impact of the global economic crisis; key emerging industries identified by the Executive Yuan were selected to set up dedicated incubation networks for the industries of biotechnology and medicine, green energy, culture \& creativity, and information \& communications technology applications; while incubators were encouraged to boost their incubation capabilities through resource sharing. This full spectrum of strategic services will be of particular benefit in revitalizing the economy. Key elements of each strategy are described below.

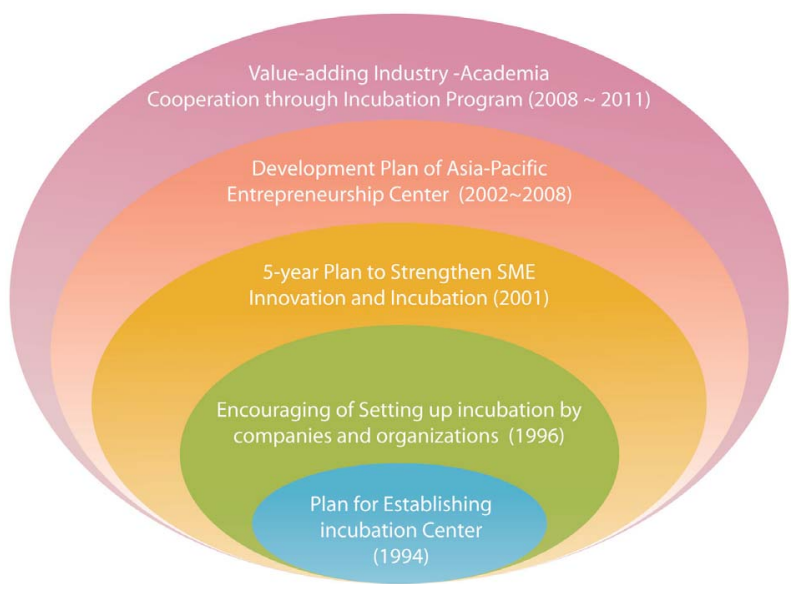

Figure 1. Evolution of incubation policy and development plans in Taiwan. Source: [29].

\subsection{Improving the Start-Up Incubation Environment}

As of 2011, there were 131 incubators in Taiwan. In order to improve quality and value-adding capability of Taiwan incubators, an effort is now under way to connect incubators, knowledgeable vendors, academia and the international incubation community in order to promote a better venture environment, improved incubation, and develop specialization.

\subsection{Assisting a Healthy Development of Incubators}

1) Analysis of incubation development issues and strategic planning: Analysis of issues and strategic planning provides a beacon for the healthy development of incubators. The aim is to build a support system focused on professionalism, performance, and government policy.

2) Improving the innovation incubation model and mechanism: The healthy development of incubators hinges on their practical management and operational reforms. From 2008 to 2011, SMEA has implemented 8 standardized counseling service systems (including Capital Finance, R \& D Management, Marketing, Intellectual Property, Innovation-Oriented Business Plan, New Product Development, Industry-Academia Cooperation Outsourcing R\& D Management, Development Path Planning); the above steps will help establish healthy incubators.

3) Incubation knowledge networking and policy promotion: Strengthen the knowledge and information on the innovation \& incubation website to expand industry-specific expert communities and help promote government policy; promote products in the market.

4) Project coordination and tracking: Tracks the current operating status of incubator graduate companies 
and has accumulated more than 1700 operating results; manages the review and evaluation of progress in incubation-related projects, holds irregular discussion meetings for internal work-related projects and propose assistance measures and development recommendations for incubatos.

5) Establish industry-specific incubation networks: It aims to effectively integrate the resources of domestic incubators and realize the full potential of counseling services, biomedical, green energy, culture and creativity, and information technology applications. The aim is to encourage cooperation and resource sharing among incubators, as well as to provide different types of incubator tenants with different needs with professional and complete services tailored to different stages of development. The operational framework is shown below in Figure 2.

\subsection{Providing Assistance Services for Industry-Academia Research Collaboration and Identifying Promising New Start-Ups (See Figure 3)}

1) Find potential industry-academia collaboration candidates and define a screening mechanism for promising cases (businesses that promise high growth, high added value, or are closely related to the industry).

2) Develop and implement a feasible service model and assistance process to promote collaborative industry-academia research projects in that particular industry and support the formation of promising new start-ups in that field.

\section{Incubation Development in Taiwan}

In January of 1995, Taiwan's SMEA, was assigned to launch SMEs Incubation Policy as one of the moves under the macro policy of "Asia Pacific Operation Center". SMEA assigned Institute of Management of Technology of National Chiao Tung University to complete the "Planning Report for Small \& Medium Enterprise Incu-

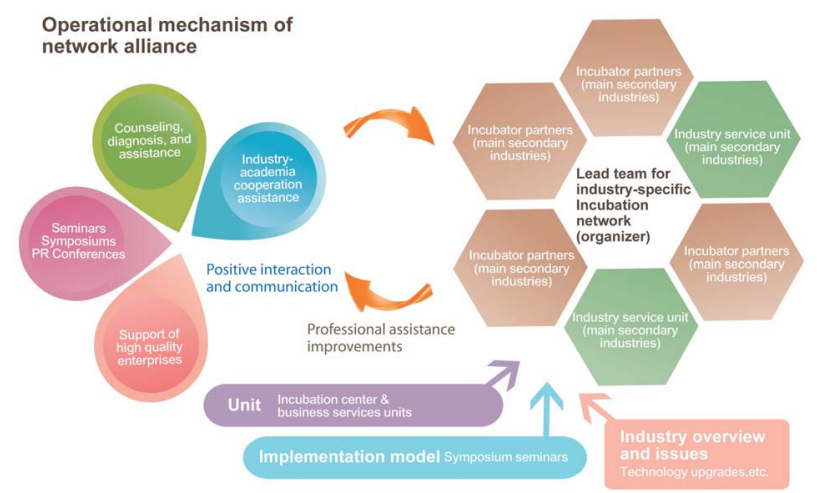

Figure 2. Framework of the industry-specific incubation network. Source: [29].

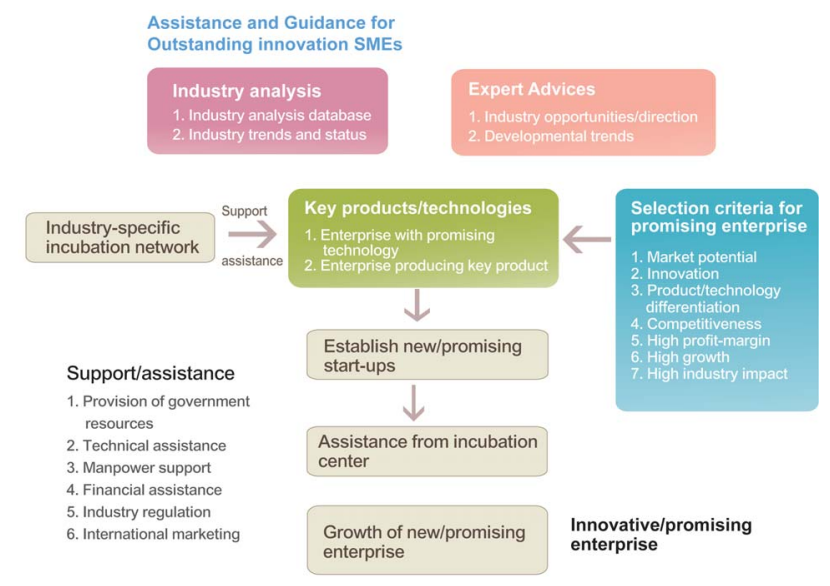

Figure 3. Selection and assistance mechanism for promising cases. Source: [29].

bators". After one year's effort, the first incubator was set up by ITRI with the assistance from SMEA.

Since then, SMEA has assisted in the establishment of about 50 incubators all over Taiwan within five years. Most of them are located within the university campuses. There are other incubators run by China Petroleum Corp. and private organizations.

The concept of setting up incubators can be traced back to 1959, when the U.S. government wanted to develop SMEs, create new jobs by subsidizing academics and individuals to integrate existing resources to supply what SMEs needed at the beginning. As we know, startups always have difficulty to get through the early stage because of lack of business operational experiences and knowledge. Though the involvement and residential programs in incubators, entrepreneurs can gain advice and required skills, including technology, finance, marketing, business law, taxation, and initial public offering, etc. Once the start-ups become strong, they can choose to leave. In the past few years, SMEA spent about 5 million US\$ each year to support the operation of the incubators. SMEA continues to facilitate the operation of the existing incubators to assure the success of those business that sign up in one of the incubators. SMEA also continues to encourage both private and public sectors to establish incubators in Taiwan.

With such incentives, incubators have sprung up all over the island, increasing from fewer than 10 in the first year of the program to the current 131.

98 of Taiwan's 131 incubators are run by universities, most of which focus more on assistance in R \& D than on the nuts and bolts of business operations. A number of them with access to a broader variety of resources combine the two objectives 1) as a platform for entrepreneurship and innovation 2) help companies advance their research capabilities and establish their business operations. 


\section{A Case Study of University Incubators in Taiwan}

In order to understand the results of incubation policy in Taiwan, we listed three national university incubators: National Taiwan University (NTU), National Chiao Tung University (NCTU) and National Cheng Kung University (NCKU). According to The Times (British) World University Ranking 2012-2013, NTU ranking is 134, NCTU ranking is 252 and NCKU ranking is 321, they are all famous for science \& technology in Taiwan, enough to show the positive results of incubation policy in Taiwan. The achievement of incubation policy is shown below in Table 1.

From the above data we understand that industrysponsored R \& D total amount in 2011 in NTU is US\$ 14 million, in NCTU is US $\$ 6.4$ million, in NCKU is US\$12 million. Compared to Massachusetts Institute of Technology (MIT) ranking is 5, MIT's industrysponsored R \& D total amount is US\$100.8 million in 2011 [30]. MIT amount is 7.2 times of NTU, 15.8 times of NCTU, 8.4 times of NCKU, so Taiwan's universities still have a room for improvement in enhancing Industry-sponsored R \& D. In order to enlarge university-industry collaboration, we need the academic institutes, industry and government to make mutual effort to reach the win-win targets. Therefore, how to create an efficient system linking incubators with industry is a serious challenge.

In order to absorbing more companies into campuses and create win-win opportunities, I think university incubators should take some steps such as:

1) Attracting more high-quality tenant applicants;

2) Obtaining more preferential treatment from service providers and venture capitalists;
3) Continually reinforcing mutual benefits accruing from the university-incubator relationship;

4) Obtaining reciprocal benefits in which the university faculty and the incubator tenants exchange ideas and knowledge that lead to technological and business innovations.

\section{Conclusions and Recommendations}

\subsection{Conclusions}

Taiwan is a relative newcomer to the incubation of businesses. The first incubators were established in the late 1990s, but the growth of the industry has been tremendous. The total of 131 incubators established more than 1500 firms with more than 60,000 employees [29]. As in most developing areas, the government played a predominant role in supporting incubators. Incubators in Taiwan offer services such as: low-cost office space, business support services, networking opportunities and tax incentives.

The entrepreneurs in Taiwan, like in other developing areas, lack financial resources, managerial skills and marketing channels. The incubators in Taiwan have to overcome typical barriers to entrepreneurship to be able to achieve success.

In this sense, the government of Taiwan uses incubators as a policy instrument to create markets opportunities. Incubators in Taiwan are financially supported via the government-established Small and Medium Enterprise Credit Guarantee Fund (SMEG) to assist enterprises with securing financial capital from banks and also provides generous seed capital funds for start-ups and funds for R \& D and innovation for small and new technologyoriented firms. The above incubation strategy will facili-

Table 1. Three national university incubators and their achivements in Taiwan.

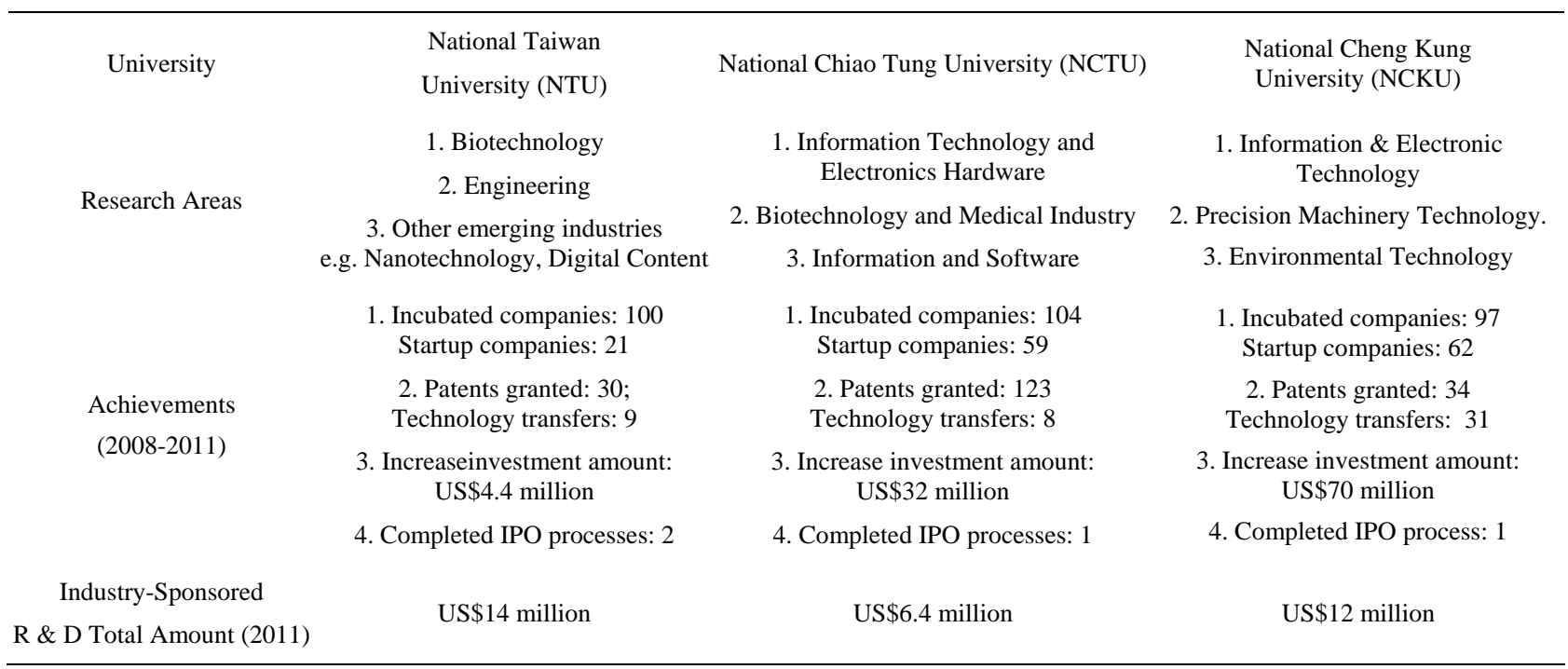

Source: [29]. 
tates the transit of incubated firms to be more competitive enterprises.

\subsection{Recommendations}

In order to promote the efficiency of incubators operation, we would like to suggest the following:

1) Reduce start-up and early stage operational costs: Very important means of reducing the risk of managerial operation are managerial and administrative assistance to help start-up incubators. So in this time related government institutions must render assistance such as: invite experts to resolve technological and managerial problems, encourage $\mathrm{R} \& \mathrm{D}$ and on-the-job training, provide tax incentives and low interest loans.

2) Enhance regional technology cooperation: Incubators are used as an effective policy tool in various areas to reduce unemployment, create new jobs, absorb investment and increase prosperity. We should strengthen regional technology cooperation (especially in the AsiaPacific Region), share the results of R \& D and promote this area's living standards.

3) Promote the efficiency of university-industry collaboration: Through incubators, universities should serve as a role model for transfer of the results of $\mathrm{R} \& \mathrm{D}$ to industry and commercialize the technologies.

4) Stimulating networking among firms: Tenant firms and entrepreneurs can benefit from peer groups membership and share similar problem solutions, businesses and working environment. Among the existing incubator models, the networked incubator helps to share resources and acquire knowledge.

5) Preventing brain drain: High-tech incubators are effectively used as a tool for absorbing immigration of high skilled foreign scientists and engineers.

Incubators can also help scientists commercialize their work and increase the financial prerequisites of scientific research. From 2005 to 2010, Science Industrial Parks in Taiwan have absorbed more than 30,000 Overseas Chinese scientists and engineers returning to Taiwan successfully preventing brain drain.

\section{REFERENCES}

[1] NBIA (National Business Incubator Association), 2010. http://www.nbia.org/resource-library/faq/\#13

[2] R. W. Smilor and M. D. Gill, "The New Business Incubator-Linking Talent, Technology, Capital and KnowHow,” Heath and Company, Massachusetts, 1986.

[3] S. A. Mian, "Assessing and Managing the University Technology Business Incubator: An Integrative Framework,” Journal of Business Venturing, Vol. 12, No. 4, 1997, pp. 251-285. doi:10.1016/S0883-9026(96)00063-8

[4] I. Hamilton-Fazey, "The UK Experience with Science Parks and Technology Incubators,” In: Organisation de coopération et de développement économiques, Technology Incubators: Nurturing Small Firms, OCDE, Paris, 1999, pp. 44-48.

[5] S. Reid and E. Garnsey, "Incubation Policy and Resource Provision: Meeting the Needs of Young, Innovative Firms,” In: R. Oakey, Ed., New Technology-Based Firms in the 1990s, Vol. 5, Paul Chapman, London, 1998, pp. 67-80.

[6] S. Geiger and M. Shane, "The Internet as a Relationship Marketing Tool-Some Evidence from Irish Companies," Irish Marketing Review, Vol. 12, No. 2, 1999, pp. 24-36.

[7] X. R. Yang, Dissemination of Research Methods of the San Min Bookstore in Taipei, Taiwan, 1996.

[8] Mei-Hui, "Content Analysis, Text Analysis and Discourse Analysis in Social Research,” Research, Eighth, 2000, pp. 5-42.

[9] D.F. Kuratko and W. R. LaFollette, "Small Business Incubators for Local Economic Development," Economic Development Review, Vol. 5, No. 2, 1987, pp. 49-55.

[10] M. P. Rice, "Co-Production of Business Assistance in Business Incubators: An Exploratory Study,” Journal of Business Venturing, Vol. 17, No. 2, 2002, pp. 163-187. doi:10.1016/S0883-9026(00)00055-0

[11] NBIA (National Business Incubator Association), University of Michigan, NBIA, Ohio University and Southern Technology Council, Business Incubation Works, 1997.

[12] S. M. Hackett and D. M. Dilts, "A Real Options-Driven Theory of Business Incubation," Journal of Technology Transfer, Vol. 29, No. 1, 2004, pp. 41-54. doi:10.1023/B:JOTT.0000011180.19370.36

[13] D. Adkins, "A Brief History of Business Incubation in the United States,” National Business Incubation Association, Athens, 2002.

[14] R. Aernoudt, “Incubators: Tool for Entrepreneurship?” Small Business Economics, Vol. 23, No. 2, 2004, pp. 127-135.

[15] H. Leblebici and N. Shah, “The Birth, Transformation and Regeneration of Business Incubators as New Organisational Forms: Understanding the Interplay between Organisational History and Organisational Theory,” Business History, Vol. 46, No. 3, 2004, pp. 353-380. doi:10.1080/0007679042000219175a

[16] T. O’Neal, “Evolving a Successful University-Based Incubator: Lessons Learned From the UCF Technology Incubator,” Engineering Management Journal, Vol. 17, No. 3, 2005, pp. 11-25.

[17] EC, "Benchmarking of Business Incubators," Final Report, Brussels, 2002.

[18] D. Allen and V. Levine, "Nurturing Advanced Technology Enterprises: Emerging Issues in State and Local Economic Development Policy,” Prager, New York.

[19] D. N. Allen and R. McCluskey, "Structure, Policy, Services and Performance in the Business Incubator Industry,” Entrepreneurship, Theory and Practice, Vol. 15, No. 2, 1986, pp. 61-77.

[20] H. Al-Mubaraki, "Procurement of International Business Incubation-Quantitative and Qualitative Approaches," 
Melrose Books, 2008. www.melrosebooks.com

[21] S. A. Mian, “Are University Technology Incubators Providing a Milieu for Technology-Based Entrepreneurship?” Technology Management, Vol. 1, 1994, pp. 86-93.

[22] R. G. Phillips, "Technology Business Incubators: How Effective as Technology Transfer Mechanism?” Technology in Society, Vol. 24, No. 3, 2002, pp. 299-316. doi:10.1016/S0160-791X(02)00010-6

[23] R. McAdam, "High Tech Start-ups in University Science Park Incubators: The Relationship between the Start-Up's Lifecycle Progression and Use of the Incubator's Resources,” Technovation, Vol. 28, No. 5, 2008, pp. 277290. doi:10.1016/j.technovation.2007.07.012

[24] H. Al-Mubaraki and M. Busler, "Business Incubators: Findings from Worldwide Survey and Guidance for the G.C.C States,” World Sustainable Development Outlook, 2009, pp. 83-91.

[25] H. Al-Mubaraki and M. Busler, "Business Incubators: Findings Fromworldwide Survey, and Guidance for the
G.C.C States,” Global Business Review, Vol. 11, No. 1, 2010, pp. 1-20. doi:10.1177/097215090901100101

[26] H. Al-Mubaraki and M. Busler, "Sustainable Development through the Inclusion of Incubator: A SWOT Analysis," World Sustainable Development Outlook, 2010, pp. 51-63.

[27] H. Al-Mubaraki and M. Busler, "Innovation, Entrepreneurship, Job Creation, Based on Incubators: International Experience," The 9th Biennial Conference on Entrepreneurship, Gandhinagar, 16-18 February 2011.

[28] European Union Regional Policy (EURP), “The Smart Guide to Innovation Based Incubators,” 2010.

http://www.ebn.eu/assets/assets/pdf/news/final_case-studi es-nma-07042010.pdf

[29] Annual Report of the Small and Medium Enterprise Administration (SMEA) Ministry of Economic Affairs, Taiwan, 2011.

[30] Massachusetts Institute of Technology (MIT) Website, 2012. http://www.mit.edu 